\title{
Effect of Different levels of Nitrogen on Growth and Yield of Rice (Oryza sativa L.) Cultivars under Terai-agro Climatic Situation
}

\author{
Biswajit Saha ${ }^{1}$, Parimal Panda ${ }^{1}$, Partha Sarathi Patra ${ }^{1}$, Ranajit Panda ${ }^{3 *}$, \\ Arindam Kundu ${ }^{2}$, A.K. Singha Roy ${ }^{1}$ and Nabakishor Mahato ${ }^{3}$ \\ ${ }^{1}$ Uttar Banga Krishi Viswavidyalaya, Pundibari, Cooch Behar, West Bengal, 736 165, India \\ ${ }^{2}$ Bidhan Chandra Krishi Viswavidyalaya, Mohanpur, Nadia, West Bengal-741252, India \\ ${ }^{3}$ Regional Research station (Old Alluvial Zone), Majhian, Patiram, UBKV, \\ D. Dinajpur-733133, West Bengal, India \\ *Corresponding author
}

\begin{tabular}{|c|c|}
\hline & A B S T R A C T \\
\hline & $\begin{array}{l}\text { An investigation was carried out during kharif seasons of } 2008 \text { in rice crop with the } \\
\text { different levels of nitrogen and various cultivars to find out best rice cultivars and } \\
\text { optimum dose of nitrogen under terai region of West Bengal. The experiment was laid out } \\
\text { in a factorial Randomized Block Design (RBD) with five cultivars namely, } \mathrm{V}_{1}=\text { MTU- }\end{array}$ \\
\hline Keywords & $\begin{array}{l}7029, V_{2}=\text { ANNADA, } V_{3}=\text { KHANDAGIRI, } V_{4}=\text { SATABDI and } V_{5}=G S-3 \text { and three } \\
\text { levels of nitrogen: } 30,60 \text { and } 90 \mathrm{~kg} / \mathrm{ha} \text {. The treatments were replicated thrice. Among the }\end{array}$ \\
\hline $\begin{array}{l}\text { Rice variety, } \\
\text { Nitrogen, } \\
\text { Terai zone. }\end{array}$ & $\begin{array}{l}\text { cultivars } \mathrm{V}_{4}(\text { Satabdi) produced tallest plant }(24.46,63.51,77.50 \text { and } 86.49 \mathrm{~cm} \text { at } 20 \text { DAT, } \\
40 \text { DAT, } 60 \text { DAT and at harvest respectively) at all the stages of taking observation. } \\
\text { Among the cultivars } \mathrm{V}_{1} \text { (MTU-7029) recorded highest number }(247.28,279.84,212.08 \\
\text { and } 205.33 \text { at } 20 \text { DAT, } 40 \text { DAT, } 60 \text { DAT and at harvest respectively. Among the levels of }\end{array}$ \\
\hline Article Info & nitrogen $\mathrm{N}_{3}(90 \mathrm{~kg} \mathrm{~N} / \mathrm{ha})$ produced maximum number of tillers $(255.20,280.06,244.64$ \\
\hline $\begin{array}{l}\text { Accepted: } \\
23 \text { June } 2017 \\
\text { Available Online: } \\
10 \text { July } 2017\end{array}$ & $\begin{array}{l}\text { and } 214.10 \text { at } 20 \text { DAT, } 40 \text { DAT, } 60 \text { DAT and at harvest respectively). Among the cultivars } \\
\mathrm{V}_{1} \text { (MTU-7029) produced longest panicle }(22.36) \text { which was statistically at par with } \\
\text { Khandagiri (22.13) and Annada (21.88). } 1000 \text { grain weight was higher (28.32) in } \mathrm{V}_{1} \\
\text { (MTU-7029) which was statistically at par with } \mathrm{V}_{2} \text { (Annada) and } \mathrm{V}_{3} \text { (Khandagiri). Among } \\
\text { the cultivars, maximum grain yield (3.56) was produced by } \mathrm{V}_{1} \text { (MTU-7029) followed by }\end{array}$ \\
\hline & $\begin{array}{l}\text { Khandagiri (3.45) Annada (3.38) and GS-3 (3.11). Cultivars MTU-7029 produced higher } \\
\text { (4.72) straw yield which was statistically at par with Khandagiri (4.58) and Annada (4.56). } \\
\text { Cultivars MTU-7029 registered highest values (42.67) of harvest index which was } \\
\text { followed by Khandagiri (42.00) and Annada (41.33). }\end{array}$ \\
\hline
\end{tabular}

\section{Introduction}

Rice (Oryza sativa), one of the most important food grain crops in the world, forms the staple diet of 2.7 billion people. It occupies 150 million hectare and producing 537 million tones with the average productivity of 3.83 tones/ha. Its cultivation is of immense important to food security of
Asia, where more than $90 \%$ of the global rice is produced and consumed. India is the largest rice growing country, while china is the largest producer of rice. In India more than $40 \%$ food grains production comes from rice which provides direct employment to about $70 \%$ of working rural people in the country. It 
forms the basis of many premier industries of India, including the textile, jute, and sugar industries. Agriculture contributes to about $31 \%$ GDP and $25 \%$ of India's exports comes from agricultural products. Being the staple food for more than $65 \%$ of the people, our national food security hangs on the growth and stability of its production. India has the largest acreage under rice about 44.6 million hectares of land under four major ecosystem viz. irrigated, rainfed lowland, rainfed upland and flood prone which occupies 21,14, 6 and 3 million hectare respectively, with a production of about 90 million tones.

Rice (Oryza sativa L.) production constitutes the major economic activity and a key source of employment for the rural population of India. India has the largest acreage under rice about 44.6 million hectares of land with a production of about 90 million tones. The total cultivated area under rice in West Bengal was 5856.8 thousand hectare during 20032004. In Cooch Behar district total area used for rice cultivation was 276.2 thousand hectare and the production was 515.4 thousand tones having the productivity of $1865 \mathrm{~kg}$ per hectare during 2003-2004. Among the crop production tools, proper time, method of sowing and nutrient management is the prerequisites that allow the crop to complete its life phase timely and successfully under specific agro- ecology.

Raza et al., (2003) claimed that number of grains per panicle and panicle length were significantly higher in $\mathrm{N}$ applied in two splits i.e. $1 / 2$ at tillering and $1 / 2$ at panicle initiation. Biloni and Bocchi (2003) observed that plant height and paddy yield were significantly affected by nitrogen application in splits and $\mathrm{N}$ applied at pre-sowing and tillering stage performed better.

The rice crop produced maximum grain yield in response to nitrogen application in three splits. Sahoo et al., (1998) concluded that number of productive tillers per hill were maximum where nitrogen was applied in three splits

Wang-Dan Ying et al., (2008) reported that rice yield was significantly increased by $\mathrm{N}$. Most of the cultivars reached the highest yields when $\mathrm{N}$ was applied at $150-225 \mathrm{~kg} / \mathrm{ha}$. As the $\mathrm{N}$ rate increased up to $225 \mathrm{~kg} / \mathrm{ha}$, 1000-grain weight and seed set rate decreased, whereas the number of grains per panicle and number of effective panicles increased.

\section{Materials and Methods}

The field experiment was carried out during kharif seasons of 2008 in rice crop with the different levels of nitrogen and various cultivars to find out best rice cultivars and optimum dose of nitrogen under terai region of West Bengal.

\section{Experimental site}

The field experiments were carried out at the instructional farm of Uttar Banga Krishi Viswavidyalaya, Pundibari, Cooch Behar, West Bengal, India. The farm is situated at 26019'86"N latitude and 89023'53" E longitude, et an elevation of 43 meter above mean sea label.

\section{Soil characteristics of the experimental site}

The topography of the land where the experimental was under taken was medium high in situation endowed with good drainage facility. The soil of the experimental field was sandy loam in texture with the $\mathrm{pH} 5.34$. Composition soil sample from all the experimental plots were collected and analyzed before sowing of the crop. The Physico-Chemical properties of the experimental soil have found are Organic Carbon (1.02\%), Available nitrogen $(94.75 \mathrm{~kg}$ $\left.\mathrm{ha}^{-1}\right)$, Available phosphorus (16.35 $\left.\mathrm{kg} \mathrm{ha}^{-1}\right)$, 
Available potassium $\left(76.90 \mathrm{~kg} \mathrm{ha}^{-1}\right)$, Total Nitrogen (211.99 $\left.\mathrm{kg} \mathrm{ha}^{-1}\right)$, Total phosphorus $\left(56.89 \mathrm{~kg} \mathrm{ha}^{-1}\right)$ and Total potassium (189.24 $\left.\mathrm{kg} \mathrm{ha}^{-1}\right)$.

\section{Details about experiment}

\section{Experimental design}

Factorial Randomized Block Design, Total area $\left(\mathrm{m}^{2}\right)$ : 780 , Plot size: 4 x 3, Number of replication: 3 , Spacing: $20 \mathrm{~cm} \times 15 \mathrm{~cm}$ and

\section{Treatment details}

Five cultivars namely MTU 7029, ANNADA, KHANDAGIRI, SATABDI and G-S 3 and three levels of nitrogen: 30,60 and $90 \mathrm{~kg} / \mathrm{ha}$.

\section{Test crop and Varieties}

Crop: Rice (Oryza sativa)

Variety: $\mathrm{V}_{1}=\mathrm{MTU}$ 7029, $\mathrm{V}_{2}=$ ANNADA, $\mathrm{V}_{3}=$ KHANDAGIRI, $\mathrm{V}_{4}=$ SATABDI and $\mathrm{V}_{5}=$ G-S 3

Methods of recording biometric observations

Leaving the border rows half of the area in each plot was earmarked for recording biometrical observation including destructive sampling and other half for recording yield components and yield.

\section{Growth parameters}

\section{Plant height}

Five plants were selected randomly from individual plots and properly tagged. Their height were measured in centimeter from the ground level. Observations were taken at 20 days interval starting from 20 days after transplanting.

\section{Dry matter accumulation (DMA)}

For calculation of DMA, destructive plant samples were taken from $50 \mathrm{~cm}$ row length of each plot at an interval of 15 days starting from 30 days after transplanting and continue upto 90 days after transplanting. From these sample plants the roots, green leaves and stems were separated and kept in brown paper packet and were allowed to dry in hot air oven at a temperature of $65^{\circ} \mathrm{C}$ for 24 hours and continued till their constant weight were recorded and from this constant weight total day matter production per square meter for each treatment was worked out.

\section{Leaf area index (LAI)}

Leaf area index (LAI) is the ratio of leaf area to the area of ground cover. For LAI calculation, the destructive plant sample were taken from $50 \mathrm{~cm}$ row length of each plot. The green leaf lamina were separated from the destructive sample and 5 leaves were randomly selected. From the central portion of the selected leaves $10 \mathrm{~cm}$ size was cut by a sharp blade. The cut portion were kept in a small brown paper packet and allowed to dry in a hot air at a temperature of $70^{\circ} \mathrm{C}$ till a constant weight were recorded. The cut leaves were then weighted on an electronic balance. On the other hand, the green leaf lamina separated from the destructive sample were separately dried and weighted. There after using area-weight $(\mathrm{a} / \mathrm{w})$ relationship of the cut leaf, total leaf area were calculated for each treatment. Then according to the formula given by Watson, 1947 LAI was calculated at 15 days interval starting from 30 days after transplantation.

Leaf area index $(\mathrm{LAI})=$

Area of total number of leaves surface

Ground area from which leaf Sample were collected 
Then the mean LAI (L) was calculated as per the formula given below.

$$
\text { Mean LAI }(L)=\frac{\mathrm{L}_{2}-\mathrm{L}_{1}}{\log _{\mathrm{e}} \mathrm{L}_{2}-\log _{\mathrm{e}} \mathrm{L}_{1}}
$$

Where, $\mathrm{L}_{1}$ and $\mathrm{L}_{2}$ are the leaf area indices at to successive occasions on time $t_{1}$ and $t_{2}$ respectively.

\section{Crop growth rate (CGR)}

Crop growth rate (CGR) expresses the gain in dry matter production of the crop per unit land area per unit time and is expressed as gram per meter square per day $\left(\mathrm{gm} \mathrm{m}^{-2} \mathrm{day}^{-1}\right)$. It is calculated according to the formula given by Watson (1952).

$$
\mathrm{CGR}=\frac{\mathrm{W}_{2}-\mathrm{W}_{1}}{\mathrm{t}_{2}-\mathrm{t}_{1}}
$$

Where, $\mathrm{W}_{1}$ and $\mathrm{W}_{2}$ were the dry weight of the aerial plant per unit area gained at time $t_{1}$ and $\mathrm{t}_{2}$ respectively.

CGR were calculated at (30-45), (45-60), (60$75)$ and (75-90) days interval.

\section{Yield attributes}

\section{Number of tillers $\left(\mathrm{m}^{-2}\right)$}

Productive and unproductive tillers were counted randomly from each variety at 20 days intervals starting from 20 days after transplanting using $1 \mathrm{~m}^{2}$ quadrate.

\section{Length of panicle $(\mathrm{cm})$}

Panicles from five hills were selected randomly from each plot prior to harvest and the panicle length was recorded $(\mathrm{cm})$ and the average length was workout.

\section{Number of grain panicle ${ }^{-1}$}

Ten panicles were randomly selected from each plot. The grains were counted for the crop of rice. Then average number of grains per panicle was workout.

\section{0 grain weight (Test weight)}

From the fresh product of the each plot, 1000 grains were collected and counted; dried and weights were recorded (g) from each plot separately.

\section{Yield and harvest index}

\section{Grain Yield (t ha-1)}

After harvesting the crop from the net plot, discarding the border rows, those were dried the sun and subsequently threshed. The produce from each in all the cases was sun dried. Clean thoroughly weight (g) and it converted per hectare basis.

$$
\text { Grain yield }\left(\mathrm{t} \mathrm{ha}^{-1}\right)=\frac{\text { Plot yield }(\mathrm{kg}) \times 10000}{\text { Plot size }\left(\mathrm{m}^{-2}\right) \times 1000}
$$

\section{Straw yield (t ha $\left.{ }^{-1}\right)$}

After threshing grain were separated from harvested material of each plot. Weight of the rest portion of the harvested parts was recorded and converted in per hectare basis.

Straw yield plot $(\mathrm{kg}) \times 10000$ Straw yield $\left(\mathrm{t} \mathrm{ha}^{-1}\right)=$ Plot size $\left(\mathrm{m}^{-2}\right) \times 1000$

\section{Harvest Index (HI)}

After harvesting and threshing, both grain and straw of individual variety were sun dried. Then the weight of grain and vegetative parts from each variety were recorded in $\mathrm{gm} \mathrm{m}^{-2}$ and then converted into $\mathrm{kg} \mathrm{ha}^{-1}$. Harvest Index 
was calculated by using the following formula and expressed in percentage (\%).

$$
\begin{gathered}
\text { H I }(\%)=\frac{\text { Economic yield (Grain) }}{\text { Biological yield (Grain + Straw) }} \\
\text { Biolo }
\end{gathered}
$$

\section{Methods of statistical analysis}

The data collected from the field and laboratory experiments were subjected to statistical analysis with appropriate design and treatment variation and were tested for significance by F-test (Cochran and Cox, 1955). The standard error of mean and critical difference is indicated in the tables. For determination of critical difference at 5\% level of significance Fisher and Yates (1963) table was consulted.

\section{Results and Discussion}

\section{Effect of nitrogen levels and cultivars on plant height $(\mathrm{cm})$ of rice}

It was revealed from the table 1 that Plant height increased continuously with the advancement of crop growth and varied significantly with different levels of nitrogen and cultivars. Among the cultivars $\mathrm{V}_{4}$ (Satabdi) produced tallest plant $(24.46,63.51$, 77.50 and $86.49 \mathrm{~cm}$ at 20 DAT, 40 DAT, 60 DAT and at harvest respectively) at all the stages of taking observation, which was statistically at par with $\mathrm{V}_{3}$ (Khandagiri) and $\mathrm{V}_{5}$ (GS-3). Whereas, cultivars $\mathrm{V}_{1}$ (MTU7029) recorded the shortest plant (22.27, $58.21,73.58$ and $83.44 \mathrm{~cm}$ ) at all the stages of crop growth. The probable reason might be due to genetic character of the cultivars.

However, among the levels of nitrogen $\mathrm{N}_{3} 90$ $\mathrm{kg} \mathrm{N} / \mathrm{ha}$ ) achieved significantly tallest plant $(24.47,62.67,76.93$ and $86.06 \mathrm{~cm}$ at 20 DAT, 40 DAT, 60 DAT and at harvest respectively) at all the stages of recording observation which was followed by $\mathrm{N}_{2}(60 \mathrm{~kg} \mathrm{~N} / \mathrm{ha})$ and $\mathrm{N}_{1}$ (30 kg N/ha). This was probably due to higher uptake of applied nitrogen and greater availability of soil nutrients. The result may be supported by the findings of Fageria and Wilcox (1977), Thakur and Singh (1987) and Sigh et al., (1996).

\section{Effect of nitrogen levels and cultivars on number of tillers $/ \mathrm{m}^{2}$}

It was clear from the table 2 that number of tillers varied from cultivars to cultivars and with the levels of nitrogen. Among the yield components, productive tillers are very important because the final yield is mainly a function of the number of panicles bearing tillers per unit area. Number of tillers increased continuously and attained a maximum value at 40 days after transplanting, which was considered as active tillering stage. After that, number of tillers decreased towards maturity due to side tiller mortality and initiation of panicle primordia. Among the cultivars $\mathrm{V}_{1}$ (MTU-7029) recorded highest number $(247.28,279.84,212.08$ and 205.33 at 20 DAT, 40 DAT, 60 DAT and at harvest respectively) of tiller $\mathrm{m}^{-2}$ which was followed by $V_{3}$ (Khandagiri) and $V_{2}$ (Annada) in all the sampling dates. Variety $\mathrm{V}_{4}$ (Satabdi) recorded lowest number of tiller $\mathrm{m}^{-2}$ in all the dates of taking observation.

Among the levels of nitrogen $\mathrm{N}_{3}(90 \mathrm{~kg} \mathrm{~N} / \mathrm{ha})$ produced maximum number of tillers $(255.20$, 280.06, 244.64 and 214.10 at 20 DAT, 40 DAT, 60 DAT and at harvest respectively) at all the stages of recording observation which was followed by $\mathrm{N}_{2}(60 \mathrm{~kg} \mathrm{~N} / \mathrm{ha})$ and $\mathrm{N}_{1}$ (30 $\mathrm{kg} \mathrm{N} / \mathrm{ha}$ ).

This was probably due to higher uptake of applied nitrogen and greater availability of soil nutrients. A similar finding was also scrutinized by Rahman et al., (2007), Hossain et al., (2002), and Tunio et al., (2002). Interaction effect of cultivars and nitrogen also depicted similar result. 
Effect of nitrogen levels and cultivars on Panicle length $(\mathrm{cm})$

A perusal of data (Table 3) revealed that length of panicle varied significantly from cultivars to cultivars and also under levels of nitrogen application. Among the cultivars $V_{1}$ (MTU-7029) produced longest panicle (22.36) which was statistically at par with Khandagiri (22.13) and Annada (21.88). However, shortest panicle (20.58) was obtained from $\mathrm{V}_{4}$ (Satabdi). This was might be to genetic character of the variety.

Among the levels of nitrogen, $\mathrm{N}_{3}(90 \mathrm{~kg} \mathrm{~N} / \mathrm{ha})$ produced longest panicle (23.39) which was followed by $\mathrm{N}_{2}(60 \mathrm{~kg} \mathrm{~N} / \mathrm{ha})$ and $\mathrm{N}_{1}(30 \mathrm{~kg}$ $\mathrm{N} / \mathrm{ha}$ ). This was probably due to higher uptake of applied nitrogen and greater availability of soil nutrients.

Effect of nitrogen levels and cultivars on percentage of filled grains

Result obtained in the present study revealed that grain filling percentage varied significantly from cultivars to cultivars. Among the cultivars $\mathrm{V}_{1}$ (MTU-7029) produced highest (90.05) percentage of fertile grains, which was statistically at par GS-3 (89.18) Khandagiri (88.34) and Annada (87.54). Higher grain filling might be due higher transportation of photosynthates from source to sink. However, cultivars Satabdi produced significantly lowest (84.75) percentage of fertile grains.

Among the levels of nitrogen, $\mathrm{N}_{3}(90 \mathrm{~kg} \mathrm{~N} / \mathrm{ha})$ produced highest (91.82) percentage of fertile grains which was followed by $\mathrm{N}_{2}(60 \mathrm{~kg}$ $\mathrm{N} / \mathrm{ha}$ ) and $\mathrm{N}_{1}$ (30 kg N/ha). This was probably due to higher uptake of applied nitrogen and greater availability of soil nutrients.

\section{Effect of nitrogen levels and cultivars on 1000 grain weight (gm)}

Thousand grains weight, an important yielddetermining component, is a genetic character and least influenced by environment (Ashraf et al., 1999). Data presented in the table 4 revealed that 1000 grain weight was higher (28.32) in $\mathrm{V}_{1}$ (MTU-7029) which was statistically at par with $\mathrm{V}_{2}$ (Annada) and $\mathrm{V}_{3}$ (Khandagiri).

Table.1 Effect of level of nitrogen and cultivars on plant height of rice

\begin{tabular}{|l|c|c|c|c|}
\hline \multirow{2}{*}{ Treatments } & \multicolumn{4}{|c|}{ Plant height } \\
\cline { 2 - 5 } & 20 DAT & 40 DAT & 60 DAT & At harvest \\
\hline $\mathrm{V}_{1}$ (MTU-7029) & 22.27 & 58.21 & 73.58 & 83.44 \\
\hline $\mathrm{V}_{2}$ (Annada) & 23.28 & 60.27 & 75.06 & 84.24 \\
\hline $\mathrm{V}_{3}$ (Khandagiri) & 24.28 & 62.79 & 77.09 & 86.02 \\
\hline $\mathrm{V}_{4}($ Satabdi) & 24.46 & 63.51 & 77.50 & 86.49 \\
\hline $\mathrm{V}_{5}(\mathrm{GS}-3)$ & 23.42 & 60.39 & 74.81 & 83.95 \\
\hline $\mathrm{S} . \mathrm{Em}( \pm)$ & 0.91 & 1.20 & 1.25 & 1.05 \\
\hline $\mathrm{CD}(\mathrm{P}=0.05)$ & 1.72 & 2.52 & 2.21 & 1.82 \\
\hline $\mathrm{N}_{1}(30 \mathrm{Kg} \mathrm{N} / \mathrm{ha})$ & 22.66 & 58.87 & 73.90 & 83.00 \\
\hline $\mathrm{N}_{2}(60 \mathrm{Kg} \mathrm{N} / \mathrm{ha})$ & 23.49 & 61.56 & 75.99 & 85.42 \\
\hline $\mathrm{N}_{3}(90 \mathrm{Kg} \mathrm{N} / \mathrm{ha})$ & 24.47 & 62.67 & 76.93 & 86.06 \\
\hline $\mathrm{S} . \mathrm{Em}( \pm)$ & 0.55 & 1.11 & 0.85 & 0.84 \\
\hline $\mathrm{CD}(\mathrm{P}=0.05)$ & 0.90 & 2.01 & 1.50 & 1.45 \\
\hline
\end{tabular}


Table.2 Effect of level of nitrogen and cultivars on number of tillers $/ \mathrm{m}^{2}$

\begin{tabular}{|l|c|c|c|c|}
\hline \multirow{2}{*}{ Treatments } & \multicolumn{4}{|c|}{ Number of tillers/ $\mathbf{m}^{\mathbf{2}}$} \\
\cline { 2 - 5 } & 20 DAT & 40 DAT & 60 DAT & At harvest \\
\hline $\mathrm{V}_{1}$ (MTU-7029) & 247.28 & 279.84 & 212.08 & 205.33 \\
\hline $\mathrm{V}_{2}$ (Annada) & 222.42 & 276.10 & 207.02 & 190.66 \\
\hline $\mathrm{V}_{3}$ (Khandagiri) & 232.76 & 279.40 & 209.22 & 202.84 \\
\hline $\mathrm{V}_{4}$ (Satabdi) & 204.38 & 264.22 & 203.84 & 180.91 \\
\hline $\mathrm{V}_{5}$ (GS-3) & 216.92 & 267.96 & 205.50 & 185.75 \\
\hline $\mathrm{S} . \mathrm{Em}( \pm)$ & 3.88 & 4.54 & 5.45 & 3.92 \\
\hline $\mathrm{CD}(\mathrm{P}=0.05)$ & 7.05 & 8.15 & 10.06 & 7.85 \\
\hline $\mathrm{N}_{1}(30 \mathrm{Kg}$ N/ha) & 192.94 & 264.00 & 191.18 & 170.10 \\
\hline $\mathrm{N}_{2}(60 \mathrm{Kg} \mathrm{N} / \mathrm{ha})$ & 226.16 & 276.54 & 204.60 & 195.09 \\
\hline $\mathrm{N}_{3}(90 \mathrm{Kg} \mathrm{N} / \mathrm{ha})$ & 255.20 & 280.06 & 244.64 & 214.10 \\
\hline $\mathrm{S} . \mathrm{Em}( \pm)$ & 17.01 & 5.12 & 12.99 & 11.91 \\
\hline $\mathrm{CD}(\mathrm{P}=0.05)$ & 32.88 & 8.59 & 26.72 & 23.25 \\
\hline
\end{tabular}

Table.3 Effect of levels of nitrogen and cultivars on yield attributes and grain yield of rice

\begin{tabular}{|c|c|c|c|c|c|c|c|}
\hline \multirow[t]{2}{*}{ Treatments } & \multicolumn{7}{|c|}{$\begin{array}{l}\text { Yield attributes and grain yield } \\
\end{array}$} \\
\hline & $\begin{array}{l}\text { Panicle } \\
\text { Length } \\
(\mathrm{cm})\end{array}$ & $\begin{array}{c}\text { Percentage } \\
\text { of filled } \\
\text { grains }\end{array}$ & $\begin{array}{l}\text { Percentage } \\
\text { of unfilled } \\
\text { grains }\end{array}$ & $\begin{array}{c}1000 \\
\text { grain } \\
\text { weight } \\
\text { (g) }\end{array}$ & $\begin{array}{l}\text { Grain } \\
\text { Yield } \\
\text { (t/ha) }\end{array}$ & $\begin{array}{l}\text { Straw } \\
\text { Yield } \\
\text { (t/ha) }\end{array}$ & $\begin{array}{c}\text { Harvest } \\
\text { Index } \\
(\%)\end{array}$ \\
\hline $\begin{array}{l}\mathrm{V}_{1} \text { (MTU- } \\
7029)\end{array}$ & 22.36 & 90.05 & 10.80 & 28.32 & 3.56 & 4.72 & 42.67 \\
\hline $\mathrm{V}_{2}$ (Annada) & 21.88 & 87.54 & 12.52 & 25.39 & 3.38 & 4.56 & 41.33 \\
\hline $\begin{array}{l}\mathrm{V}_{3} \\
\text { (Khandagiri) }\end{array}$ & 22.13 & 88.34 & 11.65 & 27.65 & 3.45 & 4.58 & 42.00 \\
\hline $\mathrm{V}_{4}$ (Satabdi) & 20.58 & 84.75 & 15.23 & 19.36 & 3.01 & 4.18 & 37.67 \\
\hline $\mathrm{V}_{5}(\mathrm{GS}-3)$ & 20.96 & 89.18 & 13.27 & 20.93 & 3.11 & 4.30 & 40.33 \\
\hline S. Em $( \pm)$ & 0.51 & 1.23 & 1.34 & 2.24 & 0.29 & 0.14 & - \\
\hline $\mathrm{CD}(\mathrm{P}=0.05)$ & 0.93 & 2.51 & 2.86 & 5.02 & 0.55 & 0.25 & - \\
\hline $\begin{array}{lll}\mathrm{N}_{1} \quad(30 & \mathrm{Kg} \\
\mathrm{N} / \mathrm{ha}) & \end{array}$ & 19.93 & 82.04 & 17.94 & 28.25 & 2.87 & 4.07 & 36.8 \\
\hline $\begin{array}{lll}\mathrm{N}_{2} & (60 & \mathrm{Kg} \\
\mathrm{N} / \mathrm{ha}) & \\
\end{array}$ & 21.43 & 88.05 & 11.98 & 29.65 & 3.19 & 4.38 & 40.8 \\
\hline $\begin{array}{l}\mathrm{N}_{3}(90 \mathrm{Kg} \mathrm{N} \\
\text { /ha) }\end{array}$ & 23.39 & 91.82 & 8.17 & 30.12 & 3.85 & 4.96 & 44.8 \\
\hline S.Em $( \pm)$ & 1.51 & 2.46 & 2.71 & 0.25 & 0.23 & 0.31 & - \\
\hline $\mathrm{CD}(\mathrm{P}=0.05)$ & 2.25 & 5.03 & 5.25 & 0.46 & 0.49 & 0.48 & - \\
\hline
\end{tabular}


Table.4 Effect of levels of nitrogen and cultivars on availability of nutrients after harvesting of rice

\begin{tabular}{|c|c|c|c|c|c|c|c|c|c|}
\hline \multirow{2}{*}{ Cultivars } & \multicolumn{3}{|c|}{ Available nitrogen $\left(\mathrm{kg} \mathrm{ha}^{-1}\right)$} & \multicolumn{3}{|c|}{ Available phosphorus $\left(\mathrm{kg} \mathrm{ha}^{-1}\right)$} & \multicolumn{3}{|c|}{ Available potassium $\left(\mathrm{kg} \mathrm{ha}^{-1}\right)$} \\
\hline & $\begin{array}{l}30 \mathrm{~kg} N \\
\text { ha }^{-1}\end{array}$ & $\begin{array}{l}60 \mathrm{~kg} \quad \mathrm{~N} \\
\mathrm{ha}^{-1}\end{array}$ & $\begin{array}{l}90 \mathrm{~kg} \mathrm{~N} \\
\mathrm{ha}^{-1}\end{array}$ & $\begin{array}{l}30 \mathrm{~kg} N \\
\mathrm{ha}^{-1}\end{array}$ & $\begin{array}{l}60 \mathrm{~kg} \mathrm{~N} \\
\mathrm{ha}^{-1}\end{array}$ & $\begin{array}{l}90 \mathrm{~kg} N \\
\mathrm{ha}^{-1}\end{array}$ & $\begin{array}{l}30 \mathrm{~kg} \mathrm{~N} \\
\mathrm{ha}^{-1}\end{array}$ & $\begin{array}{l}60 \mathrm{~kg} N \\
\mathrm{ha}^{-1}\end{array}$ & $\begin{array}{l}90 \mathrm{~kg} \mathrm{~N} \\
\mathrm{ha}^{-1}\end{array}$ \\
\hline MTU-7029 & 137.22 & 163.36 & 175.32 & 19.75 & 24.56 & 24.72 & 69.79 & 82.30 & 88.15 \\
\hline Annada & 144.10 & 151.00 & 188.11 & 19.86 & 24.61 & 32.63 & 70.22 & 72.64 & 101.45 \\
\hline Khandagiri & 213.96 & 213.75 & 225.77 & 28.76 & 29.53 & 32.54 & 88.35 & 99.25 & 117.26 \\
\hline Shatabdi & 200.84 & 238.88 & 250.66 & 30.00 & 34.42 & 37.07 & 90.56 & 96.18 & 122.35 \\
\hline GS-3 & 262.98 & 275.96 & 289.27 & 35.47 & 36.72 & 38.99 & 68.73 & 97.68 & 101.56 \\
\hline S.Em $( \pm)$ & 0.51 & 0.39 & 0.88 & 0.23 & 0.18 & 0.39 & 0.27 & 0.21 & 0.47 \\
\hline $\mathrm{CD}(\mathrm{P}=0.05)$ & 1.04 & 0.81 & 1.80 & 0.47 & 0.36 & 0.81 & 0.56 & 0.43 & 0.96 \\
\hline
\end{tabular}


This was might be due to higher conservation of light energy into chemical energy and its subsequent translocation from source to sink. Among the cultivars Satabdi recorded significantly lowest value (19.36) of 1000 grain weight.

This was might be due to lower conservation of light energy into chemical energy and its subsequent translocation from source to sink. Similar trends were also registered by Singh et al., (1986), Dhal and Misra (1993) and Tunio et al., (2002).

Among the levels of nitrogen, $\mathrm{N}_{3}(90 \mathrm{~kg} \mathrm{~N} / \mathrm{ha})$ recorded significantly higher (30.12) values of 1000 grain weight which was followed by $\mathrm{N}_{2}(60 \mathrm{~kg} \mathrm{~N} / \mathrm{ha})$ and $\mathrm{N}_{1}(30 \mathrm{~kg} \mathrm{~N} / \mathrm{ha})$. This was probably due to higher uptake of applied nitrogen and greater availability of soil nutrients.

\section{Effect of nitrogen levels and cultivars on} straw yield (t/ha)

Table 3 revealed that among the cultivars MTU-7029 produced higher (4.72) straw yield which was statistically at par with Khandagiri (4.58) and Annada (4.56). Cultivar Satabdi produce significantly lower (4.18) straw yield. The probable reason might be due to taller plant and more number of tillers corresponding to MTU-7029. Among the nitrogen levels, $90 \mathrm{~kg} \mathrm{~N} / \mathrm{ha}$ produced significantly higher (4.96) straw yield which was followed by $60 \mathrm{~kg} \mathrm{~N} / \mathrm{ha}$ (4.38) and $30 \mathrm{~kg}$ N/ha (4.07). Gulati et al., (1987), Islam et al., (1997) and Mhaskar et al., (2005) also investigated similar result.

\section{Effect of nitrogen levels and cultivars on Harvest index (\%)}

It was clearly observed from the table 3 that, harvest index varies with cultivar to cultivar and also with the different levels of nitrogen.
Among the cultivars MTU-7029 registered highest values (42.67) of harvest index which was followed by Khandagiri (42.00) and Annada (41.33). Cultivar Satabdi recoded lowest values (37.67) of harvest index, the reason might be due to lower grain and straw yield. Among the nitrogen levels, $90 \mathrm{~kg} \mathrm{~N} / \mathrm{ha}$ registered highest (44.80) value of harvest index which was followed by $60 \mathrm{~kg} \mathrm{~N} / \mathrm{ha}$ (40.80) and $30 \mathrm{~kg} \mathrm{~N} / \mathrm{ha} \mathrm{(36.80).}$

\section{Effect of nitrogen levels and cultivars on percentage of unfilled grains}

Highest percentage of sterile grain (15.23) was found under $V_{4}$ (Satabdi) which was statistically at par with $\mathrm{V}_{5}$ and $\mathrm{V}_{2}$. Cultivar MTU-7029 achieved significantly lower percentage of sterile grains (10.80). Among the levels of nitrogen, $\mathrm{N}_{3}(90 \mathrm{~kg} \mathrm{~N} / \mathrm{ha})$ produced lowest (8.17) percentage of sterile grains and $\mathrm{N}_{1}(30 \mathrm{~kg} \mathrm{~N} / \mathrm{ha})$ produced highest (17.94) percentage of sterile grains. This was probably due to higher grain filling percentage in MTU-7029.similar findings has also been reported by Tunio et al., (2002).

\section{Effect of nitrogen levels and cultivars on Grain yield (t/ha)}

Grain yield is a function of inter play of various yield components such as number of productive tillers, panicle length, percentage of grain filling and 1000 grain weight (Hassan et al., 2003). Grain yield varied significantly from cultivar to cultivar. Among the cultivars, maximum grain yield (3.56) was produced by $\mathrm{V}_{1}$ (MTU-7029) followed by Khandagiri (3.45) Annada (3.38) and GS-3 (3.11). Higher values of all growth and yield attributes ultimately produced higher grain yield corresponding to $\mathrm{V}_{1}$ (MTU-7029). Among the cultivars Satabdi produced significantly lowest grain (3.01) yield. This was probably due to lowest number of panicle meter ${ }^{-2}$, filled grains panicle ${ }^{-1}$ and lower 1000 grain weight. 
Among the levels of nitrogen, $\mathrm{N}_{3}(90 \mathrm{~kg} \mathrm{~N} / \mathrm{ha})$ produced significantly higher (3.85) grain yield which was followed by $\mathrm{N}_{2}(60 \mathrm{~kg} \mathrm{~N} / \mathrm{ha})$ and $\mathrm{N}_{1}$ (30 kg N/ha). The probable reason might be due to vigorous and enhanced plant growth and also due to continuous and synchronize supply of nutrients throughout the growth stages of rice.

\section{Effect of nitrogen levels and cultivars on} soil fertility status (kg/ha)

Availability of soil nutrients viz. Nitrogen, Phosphorus and Potassium after harvesting of rice was varied significantly from cultivar to cultivar and also with the nitrogen levels. The highest amount of available $\mathrm{N}$ was obtained in the plots where $90 \mathrm{~kg} \mathrm{~N} / \mathrm{ha}$ was applied followed by $60 \mathrm{~kg} \mathrm{~N} / \mathrm{ha}$ and $30 \mathrm{~kg} \mathrm{~N} / \mathrm{ha}$. On the contrary, highest amount of available $\mathrm{N}$ was noticed in the plot where cultivar GS-3 was grown which was followed by Khandagiri, Satabdi, Annada, and MTU7029. The higher availability of soil nitrogen might be due to less uptake of nitrogen by GS-3. The picture was also same in case of phosphorus and potassium (Table 4).

In the present research, it is clear that higher levels of nitrogen influenced most of the growth and yield parameters, considerably. Among the levels of nitrogen, $90 \mathrm{~kg}$ Nitrogen/ha recorded significantly higher grain yield and among the cultivars MTU7029 performed better in terms of growth, yield attributes and yield. Therefore, cultivars MTU-7029 with $90 \mathrm{~kg}$ Nitrogen/ha is recommended for successful rice production under the agro climatic conditions of the terai region of West Bengal.

\section{References}

Baruah, T. C. and Barthakur, H. P. (1997). A text Book of Soil Analysis, Vikas Publishing house PVT LTD, New
Delhi.

Biloni M, Bocchi S. (2003). Nitrogen application in dry seeded delayed flooded rice in Italy. Effect on yield and crop parameters. Nutr. Cycling in Agroec. 67(2), 117-128.

Bray, R. H. and Kurtz, L. T. (1945). Determination of Total, Organic and Available Forms of Phosphorus in Soils. Soil Sci. 59: 39-45.

Cochran, G. W. and Cox, M.G. (1958). Experimental Design. John Wiley and sons Inc. U.S.A.: 45-92.

Dhal, P. and Misra, G (1993). Effect of nitrogen on grain filling and yield in rice. Oryza. 30 (2):162-164.

Fageria, N. K. and Wilcox, G. E. (1977). Effect of nitrogen and phosphorus on rice growth. Lavoura-Arrozeira.30:301, 24-26.

Fisher, S.R.A. and Yates, F. (1963). Statistical Tables for Biology, Agricultural and Medical Research. Oliver and Boyd. Edinburgh Tweedale Court, London $\left(6^{\text {th }}\right.$ Edn.)

Gulati, J.M.L., Panda, S.C., Misra,B., Taha,M., Acharya,N. and Singh,N. (1987). Effect of levels of nitrogen, spacing and planting direction on rice yields. Oryza. 24:358 -362.

Hossain. M.M., Srikant. Kulkarni, Hegde. Y. R. and Angadi, V.V (2002). Effect of nitrogen levels on the incidence of blast and yield levels of rice under upland conditions of Karnataka. Plant Pathology Newsletter. 20: 17-19.

Islam, M.T; Bhowmic, R.K; Ali, M.S; Islam, M.R. (1997). Effects of nitrogen on yield attributes of high yield variety aus rice. Journal of the National Science Council of Sri Lanka. 25 (2): 113-119.

Jackson, M. L. (1967). Soil Chemical Analysis. Prentice Hall of India, Pvt. Ltd., New Delhi. pp. 183, 347, 387-408.

Jackson, M.L. (1973). Soil Chemical Analysis. Prentice-Hall of India Private 
Limited, New Delhi.

Mhaskar, N, V; Thorat, S.T and Bhagat, S.B. (2005). Effect of nitrogen levels on leaf area, leaf area index and grain yield of scented rice varieties. Journal of Soils and Crops. 15(1): 2

Rahman, M.H; Ali, M.H; Ali, M.M; Khatun, M.M. (2007). Effect of different level of nitrogen on growth and yield of transplant aman rice CV BRRI dhan32. International Journal of Sustainable Crop Production. 2(1): 28-34.

Raza, M., H. Khan, F. Karim and M.J. Tahir. (2003). Nitrogen use efficiency as affected by time of application in rice (IRRI-6). Sarhad J.Agric. 19(4): 453457.

Sahoo, N.C., R.K. Mishra and J.P. Mohanty. (1998). Effect of single versus split application of nitrogen on growth and physiological growth parameters of rice. Orissa J. Agric. Res. 2(3-4): 191-195.

Singh, B., Katyal, J.C., Malhotra, P.K. and Vlek, P.L.G. (1986). Path coefficient analysis of $\mathrm{N}$ nutrition on yield and yield components for rice in a highly percolating soil. Communications in soil science and plant analysis.17 (8): 853867.

Singh, Y., Chaudhary, D.C., Singh, S.P.,
Bhardwaj, A.K. and Singh, D. (1996).Sustainability of rice (Oryza sativa)-wheat (Triticum aestivum) sequential cropping through introduction of legume crops and green manure crops in the system. Indian $J$. Agron. 41(4):510-514.

Thakur, K.S. and Singh, C.N. (1987). Effect of organic wastes and $\mathrm{N}$ levels on transplanted rice. Indian J.Agron. 32 (2): 161-164

Tunio, G. S; Agustin, M.B; Nihal-ud-dinMari; Babar, M.A. (2002). Growth and yield of scented rice varieties under different nitrogen levels. Sarhad Journal of Agriculture. 18: 3, 303-305

Walkley, A. and I. A. Black. (1934). An examination of Degtjareff method for determining soil organic matter and a proposed modification of the chromic acid titration method. Soil Sci. 37: 2937.

Wang-DanYing; Zhang-XiuFu; ShaoGuoSheng; Xu-ChunMei (2008). Response of grain yield of different Japonica rice cultivars to amount of nitrogen application in high-fertility paddy field. Acta-Agronomica-Sinica. 34(9): 1623-1628.

\section{How to cite this article:}

Biswajit Saha, Parimal Panda, Partha Sarathi Patra, Ranajit Panda, Arindam Kundu, A. K. Singha Roy and Nabakishor Mahato. 2017. Effect of Different levels of Nitrogen on Growth and Yield of Rice (Oryza sativa L.) Cultivars under Terai-agro Climatic Situation. Int.J.Curr.Microbiol.App.Sci. 6(7): 2408-2418. doi: https://doi.org/10.20546/ijcmas.2017.607.285 